\title{
Crop-livestock integration and the physical resilience of a degraded Latosol
}

\section{Integração agricultura-pecuária e resiliência física de um Latossolo degradado}

\author{
José Fausto Guimarães Silva'; Wainer Gomes Gonçalves²; Kátia Aparecida de \\ Pinho Costa ${ }^{3}$; José Flávio Neto ${ }^{2}$; Marlete Ferreira de Brito ${ }^{1}$; Felipe Carreira da \\ Silva $^{1}$; Eduardo da Costa Severiano ${ }^{3 *}$
}

\begin{abstract}
The degradation of pastures in Brazil is a problem of agronomic and environmental importance because it impairs the productive capacity of the soil and the hydrological cycle. In this context, the integration of agriculture and livestock emerges as a promising practice in recovering degraded soils through aggregation, increasing organic carbon in the soil and breaking compacted layers via the growth of grass roots. This study aimed to evaluate suitable indicators of physical quality in regard to mitigating structural changes of a Latosol cultivated with different species of the genus Brachiaria. We evaluated the grasses Brachiaria brizantha (Xaraés, Piatã, Marandu), Brachiaria decumbens and Brachiaria ruziziensis and adopted fallow and conventional tillage as controls. Soil samples were used to evaluate the parameters total organic carbon, soil aggregation via wet sieving and the least limiting water range (LLWR). Total organic carbon and aggregate stability were not suitable indicators for quantifying soil structural changes, remaining high in the evaluated conservation systems, with a difference observed only in the control with conventional tillage. The LLWR varied among all systems and layers evaluated. Xaraés palisadegrass, followed by the Piatã and Marandu cultivars, stood out in terms of biological soil loosening ability, being similar to the recovery caused by soil tillage. Furthermore, $B$. decumbens showed intermediate performance, while B. ruziziensis showed activity similar to that in the fallow treatment, indicating limited potential for soil physical recovery.
\end{abstract}

Key words: Aggregate stability. Biological soil loosening. Brachiaria sp. Least limiting water range. Soil structural quality.

\section{Resumo}

A degradação das pastagens no Brasil é um problema de ordem agronômica e ambiental, pois compromete a capacidade produtiva do solo e o ciclo hidrológico. Neste contexto, a integração agricultura-pecuária surge como uma prática promissora na recuperação de solos degradados, através da agregação, aumento dos estoques de carbono no solo e do rompimento de camadas compactadas pelo crescimento radicular das gramíneas. Este trabalho objetivou avaliar o indicador adequado de qualidade física na mitigação da compactação de um Latossolo cultivado com espécies do gênero Brachiaria.

1 Discentes, Instituto Federal de Educação, Ciência e Tecnologia Goiano, Campus Rio Verde, Rio Verde, GO, Brasil. E-mail: jfausto_ufrrj@yahoo.com.br; marleterv@gmail.com; felipe.carreira@ruralempresas.com.br

2 Pesquisadores, Instituto Federal de Educação, Ciência e Tecnologia Goiano, Campus Rio Verde, Rio Verde, GO, Brasil. E-mail: wainer.goncalves@ifgoiano.edu.br; jose.flavio@ifgoiano.edu.br

3 Profs., Instituto Federal de Educação, Ciência e Tecnologia Goiano, Campus Rio Verde, Rio Verde, GO, Brasil. E-mail: katia. costa@ifgoiano.edu.br; eduardo.severiano@ifgoiano.edu.br

* Author for correspondence 
Foram avaliadas as gramíneas: Brachiaria brizantha (Xaraés, Piatã, Marandu); Brachiaria decumbens e Brachiaria ruziziensis. Adotou-se como controle: pousio e cultivo convencional. Amostras de solo foram utilizadas para avaliar o carbono orgânico total, a agregação do solo via peneiramento úmido e o intervalo hídrico ótimo (IHO). O carbono orgânico e a estabilidade dos agregados não foram indicadores adequados para quantificação das alterações estruturais do solo, permanecendo alta nos sistemas de conservação avaliados e diferindo apenas do controle com preparo convencional. O IHO variou entre todos os sistemas e camadas avaliadas. O capim Xaraés, seguido por Piatã e Marandu, destacou-se na escarificação biológica do solo, similarmente à recuperação via preparo do solo, e $B$. decumbens apresentou desempenho intermediário, enquanto B. ruziziensis apresentou atividade semelhante ao pousio, indicando potencial limitado de recuperação física do solo.

Palavras-chave: Brachiaria sp. Escarificação biológica do solo. Estabilidade de agregados. Intervalo hídrico ótimo. Qualidade estrutural do solo.

\section{Introduction}

Brazil is highlighted in terms of the production and export of beef, and such animal production is predominantly conducted in pastures. The producing regions in the Cerrado biome correspond to approximately 49.5 million hectares of grassland, accounting for approximately $30 \%$ of the cultivated area (SANO et al., 2010) and $50 \%$ of the meat produced in the country. Half of the pastures, however, are experiencing a decline in productivity, particularly as a result of ageing or overgrazing (FERREIRA et al., 2013).

On the other hand, Brazil has established a farming system that contributes to ensuring global food security (TOLLEFSON, 2010). This is because, for the soil to play its essential role in the environment and produce food, it is necessary to preserve its structure, especially through practices that maintain soil functions, particularly the management of soil compaction (SEVERIANO et al., 2011).

Soil compaction is a serious environmental problem whose impact on the soil structure promotes the degradation of environment, with increased emissions of carbon and other greenhouse gases, increased erosion and consequent siltation of waterways (HORN et al., 1995; NAWAZ et al., 2013).

The adoption of conservation agriculture systems greatly favours the quality of the soil and the environment in which they occur (VEZZANI; MIELNICZUK, 2009). In this context, the implementation of crop-livestock integration systems represents a tool for soil structure recovery
(SOUZA et al., 2010; CHIODEROLI et al., 2012) and has been successfully conducted in South America (GARCÍA-PRÉCHAC et al., 2004).

Among the grasses used in these systems, Brachiaria (Trin.) Griseb. spp. (syn. Urochloa P. Beauv. spp.) are the most important forages (CRUVINEL et al., 2017). Currently, the breeding programme for this genus promoted by Embrapa (Brazilian Agricultural Research Corporation) is developing cultivars suitable for the cultivation conditions of the regional producing environments (MAIA et al., 2014).

In addition, these species can promote biological soil loosening (SILVA et al., 2014; FLÁVIO NETO et al., 2015), minimizing compaction by machinery traffic and animal trampling, especially that managed under no-tillage and promoting nutrient cycling (PACHECO et al., 2011) and the production of straw (NUNES et al., 2006), which has enabled the adoption of integrated production systems in tropical conditions of the Brazilian Cerrado. For these reasons, Brachiaria pastures are noteworthy, especially those containing the species $B$. brizantha, $B$. decumbens, and B. ruziziensis.

In turn, grass cultivation has positive effects on soil structure, especially when grown in the offseason of summer crops in anticipation of no-tillage (PÉRÈS et al., 2013; SILVA et al., 2014). These benefits are due to the continuous renewal of roots and input of plant waste to the soil (OADES, 1984; SILVA; MIELNICZUK, 1998). However, in the Brazilian Cerrado, this period is characterized as a 
dry winter, which could limit the development of grasses that are less tolerant to drought.

Soil quality stands out in terms of its functional role in the ecosystem by preserving environmental quality, supporting biological productivity and promoting plant and animal health (SOIL SCIENCE GLOSSARY TERMS COMMITTEE, 2008). In this context, the physical attributes of the soil can influence its potential quality because these attributes are affected by the management approaches to which the soil is subjected. Thus, soil physical quality indicators can be used to identify the structural changes the soils have undergone that have led to their degradation (LEÃO et al., 2006).

Among the indicators of the structural condition of the soil, soil aggregation measures are associated with cementing agents of organic origin (KONG et al., 2005; RAWLINS et al., 2013; MONCADA et al., 2013). Soil aggregation, at first, is closely related to the ability of the soil to resist degradation, thus indicating changes in soil management (ZOTARELLI et al., 2005).

The evaluation of aggregate stability, although widely conducted (RAWLINS et al., 2013), should be associated with other indicators (MONCADA et al., 2013). In this sense, the least limiting water range (LLWR) is a complementary alternative to evaluate soil structural conditions (OLIBONE et al., 2010; LIMA et al., 2012).

The LLWR is an indicator representing the soil water content range at which there are minimal physical constraints to the growth of plants related to water availability, air supply and the mechanical resistance of the soil matrix to root growth. This is a multifactorial index that decreases with increasing soil compaction until the critical bulk density $(\mathrm{Bd})$ of the soil is reached, at which its value is null (SILVA et al., 2006a).

Considering the importance of sustainable agriculture and livestock production in Brazil, the present study evaluated the physical recovery of a Distroferric Red Latosol subjected to croplivestock integration systems with the cultivation of Brachiaria species through the use of soil structure quality indicators and factors limiting the LLWR and aggregation of the soil.

\section{Materials and Methods}

\section{Study area and site description}

The study was conducted at the Experimental Field of the Federal Institute of Education, Science and Technology Goiano, Campus Rio Verde, state of Goiás, Brazil (1748’34” S and 5054'05” W) in an area of $2016 \mathrm{~m}^{2}$, with a clayey Distroferric Red Latosol (SANTOS et al., 2018) (Table 1), cultivated with Brachiaria decumbens for 10 years in an extensive grazing system. The climate is classified according to Köppen as tropical wet (Aw), tropical savannah subtype, with a dry winter and rainy summer.

Table 1. Physical and chemical characterization of the Distroferric Red Latosol in the municipality of Rio Verde, state of Goiás.

\begin{tabular}{|c|c|c|c|c|c|c|c|c|}
\hline \multirow{2}{*}{$\mathrm{Pd}^{(1)}$} & \multirow{2}{*}{$\mathrm{Bd}^{(2)}$} & \multicolumn{7}{|c|}{ Particle size analysis ${ }^{(3)}$} \\
\hline & & VCS & $\mathrm{CS}$ & MS & FS & VFS & Silt & Clay \\
\hline 2.8 & 1.2 & 1 & 15 & 154 & 141 & 53 & 195 & 441 \\
\hline \multicolumn{9}{|c|}{${\text { Sulfuric acid } \text { attack }^{(4)}}^{(4)}$} \\
\hline \multicolumn{2}{|c|}{$\mathrm{SiO}_{2}$} & \multicolumn{2}{|c|}{$\mathrm{Al}_{2} \mathrm{O}_{3}$} & \multicolumn{2}{|c|}{$\mathrm{Fe}_{2} \mathrm{O}_{3}$} & \multicolumn{2}{|c|}{$\mathrm{Ki}$} & $\mathrm{Kr}$ \\
\hline \multicolumn{2}{|c|}{4.1} & \multicolumn{2}{|c|}{20.4} & \multicolumn{2}{|c|}{20.4} & \multicolumn{2}{|c|}{0.34} & 0.21 \\
\hline
\end{tabular}

(1) Particle density in the $0-0.2 \mathrm{~m}$ layer; (2) soil bulk density of the $0-0.2 \mathrm{~m}$ layer; ${ }^{(3)}$ determined by the pipette method for the $0-0.2 \mathrm{~m}$ layer; ${ }^{(4)}$ determined for the Bw horizon (1.00-1.20 m). VCS: very coarse sand; CS: coarse sand; MS: medium sand; FS: fine sand; VFS: very fine sand; $\mathrm{Ki}$ : $\mathrm{SiO}_{2} / \mathrm{Al}_{2} \mathrm{O}_{3}$ molecular ratio; $\mathrm{Kr}$ : $\mathrm{SiO}_{2} /\left(\mathrm{Al}_{2} \mathrm{O}_{3}+\mathrm{Fe}_{2} \mathrm{O}_{3}\right)$ molecular ratio. 
In the pasture recovery process, we conducted the experiment during the 2010/2011 growing season with thirty-two plots of 5.4 x 6 metres (32.4 $\mathrm{m}^{2}$ ) randomly placed into four blocks and grown with corn (Zea mays) with a spacing of $0.88 \mathrm{~m}$ between rows.

Thirty days after corn emergence, Brachiaria grasses were overseeded into the plots for the implementation of the crop-livestock integration system, which consisted of the following treatments using $9 \mathrm{~kg} \mathrm{ha}^{-1}$ of pure and viable seeds: (1) Brachiaria brizantha cv. Xaraés (BbX); (2) Brachiaria brizantha cv. Piatã (BbP); (3) Brachiaria brizantha cv. Marandu (BbM); (4) Brachiaria decumbens cv. Basilisk (Bdec) and (5) Brachiaria ruziziensis $(B r)$. The Xaraés, Piatã and Marandu palisadegrasses were obtained from the breeding programme of Embrapa.

For comparison, we adopted the following as control treatments: (6) no cultivation of Brachiaria, leaving the soil fallow and with weeds (Fallow), and comprised predominantly of a canopy of dicot weeds in terms of density and diversity, as described by Flávio Neto et al. (2015) and (7) conventional tillage, which was performed by mechanical recovery via ploughing and harrowing the soil with a rotary tiller (CT) during the implementation of the subsequent agricultural calendar at the end of the cultivation of the off-season pastures in the integrated treatments. This operation was carried out when the soil water content was close to field capacity.

In November 2011, we sowed corn for silage for 90 days. Next, the development of grasses was monitored by evaluating the increase in dry matter production, which varied according to seasonality. The grasses growing in the pastures were cut to $0.2 \mathrm{~m}$, and the residues were removed. Cutting was performed in March, May, July, September, October and November 2011, and information regarding the performance of these forage plants can be found in Maia et al. (2014).

\section{Sampling protocol}

To evaluate the structural recovery of the soil promoted by the cultivation of the studied grasses, undisturbed and random soil sampling was conducted in each plot during the 2011/2012 growing season. The samples were collected at $0-0.1,0.1-0.2$ and $0.2-0.3 \mathrm{~m}$ deep using metal rings $0.064 \mathrm{~m}$ in diameter and $0.05 \mathrm{~m}$ in height. The samples were then wrapped in PVC film.

At the same time, monoliths were collected by creating small trenches in the experimental plots across the same layers described above for the subsequent assessment of soil aggregates. The monoliths were removed with the aid of spatulas and packaged in plastic containers to maintain their integrity until their evaluation in the laboratory.

\section{Soil aggregation analysis}

In the laboratory, the monoliths were initially broken by hand through the disruption of soil clods at the point of greatest weakness, and aggregates that were 4.76 to $8.00 \mathrm{~mm}$ diameter were obtained by sieving the undisturbed material. The aggregate stability in water was determined according to the principle of slow wetting by capillarity, as described by Kemper and Rosenau (1986). To this end, the samples were placed in a vertical oscillation device on a series of sieves of 2.00, 1.00, 0.50, 0.25 and $0.106 \mathrm{~mm}$ mesh size, as described by Yoder (1936). Subsequently, the content retained on each sieve was transferred to an aluminium can, which was placed in an oven at $110^{\circ} \mathrm{C}$ for 24 hours. The geometric mean diameter (GMD) of the aggregates was determined according to Kemper and Chepil (1965).

We also determined the total organic carbon (TOC) content in the soil from the surplus material resulting from the initial preparation of the monoliths according to Teixeira et al. (2017). 


\section{Least limiting water range}

Undisturbed soil samples were collected to determine the least limiting water range (LLWR). After initial saturation, the samples were subjected to a matric potential of $-6 \mathrm{kPa}$ to determine their field capacity, as described by SEVERIANO et al. (2011) for Latosols in the Brazilian Cerrado. Next, the soil water content was adjusted to range from 0.04 to $0.53 \mathrm{dm}^{3} \mathrm{dm}^{-3}$ for penetrometer testing, as proposed by Leão et al. (2006).

Then, the samples were oven dried at $105^{\circ} \mathrm{C}$ for 48 hours to determine their soil Bd and total porosity (TP) (TEIXEIRA et al., 2017).

A penetration resistance curve (PRC) was generated by adjusting the penetration resistance (PR) values according to the volumetric water content $(\theta)$ and $\mathrm{Bd}$ according to the non-linear model proposed by Busscher (1990). The empirical parameters of adjustment were obtained by minimizing the sum of squares of the difference between the determined values and those estimated by the models using algorithms in spreadsheets according to Leão and Silva (2004). The obtained $\mathrm{PRC}$ is expressed by equation 1 :

$$
\mathrm{PRC}=0.34 \theta^{-0.78} \mathrm{Bd}^{5.65} ; R^{2}=0.82^{* *} \quad \text { Eq. } 1
$$

The LLWR was determined according to the procedures described in Silva et al. (1994) considering as the upper limits the water content in the soil retained at the matric potential of $-6 \mathrm{kPa}$ as the field capacity $\left(\theta_{\mathrm{FC}}\right)$ (SEVERIANO et al., 2011) and/or that at which the air-filled porosity $\left(\theta_{\mathrm{AFP}}\right)$ is $10 \%$.
The lower limits were the water content retained at the matric potential of $-1500 \mathrm{kPa}$ and/ or the permanent wilting point $\left(\theta_{\mathrm{PWP}}\right)$ corresponding to the penetration resistance of $2.5 \mathrm{MPa}\left(\theta_{\mathrm{PR}}\right)$ (SEVERIANO et al., 2011), using at Eq. 1.

The LLWR was determined by adjusting the limits of soil water content according to the soil $\mathrm{Bd}$. The upper limit is the lowest value between $\theta_{\mathrm{FC}}$ and $\theta_{\mathrm{AFP}}$, and the lowest limit is the highest value between $\theta_{\mathrm{PWP}}$ and $\theta_{\mathrm{PR}}$.

\section{Statistical analysis}

The results of the soil aggregation and TOC analysis were subjected to analysis of variance according to a randomized block design, and the means were compared with the Scott-Knott test at 5\% probability. In addition, the Pearson correlation coefficient (r) was used to evaluate the correspondence between the TOC data and those regarding soil aggregation and the LLWR to evaluate the relevance of these soil physical quality indicators.

\section{Results}

The total organic carbon (TOC) content in the soil varied among the evaluated Brachiaria species and soil layers (Table 2). At the soil surface (0-0.1 $\mathrm{m})$, the presence of the cultivars of $B$. brizantha $(B b)$ and $B$. decumbens $(B d e c)$ somewhat promoted the TOC content. The plots in the B. ruziziensis $(B r)$ and fallow treatments had intermediate values of TOC content, while the lowest TOC content was found under conventional tillage (CT). 
Table 2. Total organic carbon (TOC) in different layers of a Distroferric Red Latosol after cultivation with different types of vegetation cover in the municipality of Rio Verde, state of Goiás.

\begin{tabular}{lccc}
\hline \multirow{2}{*}{ Treatments } & \multicolumn{3}{c}{ TOC $\mathbf{( \mathbf { g ~ d m } ^ { - 3 } )}$} \\
\cline { 2 - 4 } & $\mathbf{0 - 0 . 1} \mathbf{~ m}$ & $\mathbf{0 . 1 - 0 . 2} \mathbf{~ m}$ & $\mathbf{0 . 2 - 0 . 3 ~} \mathbf{~}$ \\
\hline$B b \mathrm{X}$ & $35.5 \mathrm{a}$ & $26.7 \mathrm{c}$ & $24.3 \mathrm{a}$ \\
$B b \mathrm{P}$ & $34.5 \mathrm{a}$ & $30.0 \mathrm{~b}$ & $26.3 \mathrm{a}$ \\
$B b \mathrm{M}$ & $33.9 \mathrm{a}$ & $28.1 \mathrm{c}$ & $26.2 \mathrm{a}$ \\
$B d e c$ & $35.8 \mathrm{a}$ & $27.8 \mathrm{c}$ & $26.2 \mathrm{a}$ \\
$B r$ & $30.5 \mathrm{~b}$ & $26.4 \mathrm{c}$ & $27.2 \mathrm{a}$ \\
Fallow & $31.0 \mathrm{~b}$ & $26.7 \mathrm{c}$ & $20.4 \mathrm{~b}$ \\
CT & $23.7 \mathrm{c}$ & $33.6 \mathrm{a}$ & $27.1 \mathrm{a}$ \\
\hline
\end{tabular}

BbX: Brachiaria brizantha cv. Xaraés; BbP: Brachiaria brizantha cv. Piatã; BbM: Brachiaria brizantha cv. Marandu; Bdec: Brachiaria decumbens; Br: Brachiaria ruziziensis; CT: conventional tillage. For the same layer, values followed by different letters are significantly different according to the Scott-Knott test $(\mathrm{P} \leq 0.05)$.

On the other hand, in the 0.1-0.2 m layer, the highest TOC content occurred in the soil under CT. It is noteworthy that the TOC content of the soil under $B b \mathrm{P}$ was greater than that under the other species of Brachiaria, which had the lowest concentrations of TOC, similar to that found in the fallow treatment (Table 2).

Within the 0.2-0.3 $\mathrm{m}$ layer, the highest values of TOC content were found in the soil under the cultivation of grasses and CT.

Table 3 shows that in all evaluated systems and layers except for the CT, which had the lowest values, there was no difference in the geometric mean diameter (GMD) of aggregates. In general, the GMD values remained high even in all layers in the treatments without soil revolving (e.g., no Brachiaria cultivation and crop-livestock integration).
Regarding the distribution of aggregates among size classes, more than $95 \%$ of the aggregates were stable in water and were retained on all sieves $\geq 0.25$ $\mathrm{mm}$ in mesh size across all treatments and layers (Table 3). More than $90 \%$ of the soil aggregates were classified into the largest size class $(2-8 \mathrm{~mm})$ for treatments without soil revolving and across all evaluated layers (Table 3).

The assessment of the LLWR (Figure 1) demonstrated differential effects of the grasses on the soil structuring process. Among the limits that influence the LLWR, the water content at which the resistance to the critical penetration of $2.5 \mathrm{MPa}$ was reached $\left(\theta_{\mathrm{PR}}\right)$ most affected its amplitude, especially at increasing soil depths.

In contrast, the minimal aeration porosity of $10 \%$ did not limit the LLWR in any treatment or layer (Figure 1). 
Table 3. Geometric mean diameter (GMD) and classification of aggregates according to size class in a Distroferric Red Latosol in the municipality of Rio Verde, state of Goiás.

\begin{tabular}{|c|c|c|c|c|c|c|c|}
\hline \multirow{3}{*}{ Treatments } & \multirow{2}{*}{ GMD } & \multicolumn{6}{|c|}{ Size classes } \\
\hline & & $\mathbf{A}$ & B & $\mathrm{C}$ & D & $\mathbf{E}$ & $\mathbf{F}$ \\
\hline & $(\mathbf{m m})$ & \multicolumn{6}{|c|}{ - } \\
\hline & \multicolumn{7}{|c|}{ 0-0.1 m layer } \\
\hline$B b \mathrm{X}$ & $4.6 \mathrm{a}$ & $97.7 \mathrm{a}$ & $0.3 \mathrm{a}$ & $0.3 \mathrm{a}$ & $0.7 \mathrm{~b}$ & $0.4 \mathrm{~b}$ & $0.6 \mathrm{~b}$ \\
\hline$B b \mathrm{P}$ & $4.6 \mathrm{a}$ & $97.7 \mathrm{a}$ & $0.2 \mathrm{a}$ & $0.3 b$ & $0.7 \mathrm{~b}$ & $0.4 \mathrm{~b}$ & $0.8 \mathrm{~b}$ \\
\hline$B b \mathrm{M}$ & $4.4 \mathrm{a}$ & $95.4 \mathrm{a}$ & $0.8 \mathrm{a}$ & $0.8 b$ & $1.1 \mathrm{~b}$ & $0.7 \mathrm{~b}$ & $1.2 \mathrm{~b}$ \\
\hline Bdec & $4.5 \mathrm{a}$ & $96.5 \mathrm{a}$ & $0.7 \mathrm{a}$ & $0.5 b$ & $0.9 \mathrm{~b}$ & $0.5 \mathrm{~b}$ & $0.9 \mathrm{~b}$ \\
\hline$B r$ & $4.3 \mathrm{a}$ & $93.6 \mathrm{a}$ & $1.5 \mathrm{a}$ & $1.3 b$ & $1.7 \mathrm{~b}$ & $1.1 \mathrm{~b}$ & $0.9 \mathrm{~b}$ \\
\hline Fallow & $4.3 \mathrm{a}$ & $95.1 \mathrm{a}$ & $0.8 \mathrm{a}$ & $0.8 \mathrm{~b}$ & $1.2 \mathrm{~b}$ & $0.9 \mathrm{~b}$ & $1.2 \mathrm{~b}$ \\
\hline \multirow[t]{2}{*}{$\mathrm{CT}$} & $3.0 \mathrm{~b}$ & $81.3 \mathrm{~b}$ & $2.7 \mathrm{a}$ & $3.3 b$ & $5.3 \mathrm{~b}$ & $3.6 \mathrm{a}$ & $3.8 \mathrm{a}$ \\
\hline & \multicolumn{7}{|c|}{ 0.1-0.2 m layer } \\
\hline$B b \mathrm{X}$ & $4.6 \mathrm{a}$ & $97.5 \mathrm{a}$ & $0.3 b$ & $0.2 \mathrm{~b}$ & $0.6 b$ & $0.5 \mathrm{~b}$ & $1.0 \mathrm{a}$ \\
\hline$B b \mathrm{P}$ & $4.5 \mathrm{a}$ & $96.9 \mathrm{a}$ & $0.3 \mathrm{~b}$ & $0.4 \mathrm{~b}$ & $0.8 b$ & $0.6 \mathrm{~b}$ & $0.9 \mathrm{a}$ \\
\hline$B b \mathrm{M}$ & $4.3 \mathrm{a}$ & $94.6 \mathrm{a}$ & $1.0 \mathrm{~b}$ & $1.1 \mathrm{~b}$ & $1.6 \mathrm{~b}$ & $1.1 \mathrm{~b}$ & $0.6 \mathrm{a}$ \\
\hline Bdec & $4.6 \mathrm{a}$ & $97.3 \mathrm{a}$ & $0.3 b$ & $0.3 b$ & $0.7 \mathrm{~b}$ & $0.5 \mathrm{~b}$ & $1.0 \mathrm{a}$ \\
\hline$B r$ & $4.4 \mathrm{a}$ & $94.9 \mathrm{a}$ & $1.1 \mathrm{~b}$ & $0.9 b$ & $1.2 \mathrm{~b}$ & $0.8 \mathrm{~b}$ & $1.0 \mathrm{a}$ \\
\hline Fallow & $4.6 \mathrm{a}$ & $96.8 \mathrm{a}$ & $0.4 \mathrm{~b}$ & $0.6 \mathrm{~b}$ & $1.0 \mathrm{~b}$ & $0.6 \mathrm{~b}$ & $0.7 \mathrm{a}$ \\
\hline \multirow[t]{2}{*}{ CT } & $3.4 \mathrm{~b}$ & $85.7 \mathrm{~b}$ & $2.2 \mathrm{~b}$ & $2.4 \mathrm{a}$ & $3.9 \mathrm{a}$ & $4.5 \mathrm{a}$ & $1.4 \mathrm{a}$ \\
\hline & \multicolumn{7}{|c|}{ 0.2-0.3 m layer } \\
\hline$B b \mathrm{X}$ & $4.5 \mathrm{a}$ & $96.2 \mathrm{a}$ & $0.76 b$ & $0.60 \mathrm{~b}$ & $1.0 \mathrm{~b}$ & $0.7 \mathrm{~B}$ & $0.8 \mathrm{~B}$ \\
\hline$B b \mathrm{P}$ & $4.5 \mathrm{a}$ & $96.8 \mathrm{a}$ & $0.46 b$ & $0.43 b$ & $0.8 \mathrm{~b}$ & $0.6 \mathrm{~B}$ & $0.9 \mathrm{~B}$ \\
\hline$B b \mathrm{M}$ & $4.1 \mathrm{a}$ & $92.3 \mathrm{a}$ & $1.68 \mathrm{~b}$ & $1.60 \mathrm{~b}$ & $2.1 \mathrm{~b}$ & $1.4 \mathrm{~B}$ & $1.0 \mathrm{~B}$ \\
\hline Bdec & $4.3 \mathrm{a}$ & $94.1 \mathrm{a}$ & $1.25 \mathrm{~b}$ & $1.01 \mathrm{~b}$ & $1.5 \mathrm{~b}$ & $0.9 \mathrm{~B}$ & $1.3 \mathrm{~B}$ \\
\hline$B r$ & $4.0 \mathrm{a}$ & $91.1 \mathrm{a}$ & $2.24 \mathrm{a}$ & $1.52 \mathrm{~b}$ & $2.1 \mathrm{~b}$ & $1.3 \mathrm{~B}$ & $1.7 \mathrm{~B}$ \\
\hline Fallow & $4.4 \mathrm{a}$ & $94.8 \mathrm{a}$ & $1.25 \mathrm{~b}$ & $1.06 \mathrm{~b}$ & $1.3 \mathrm{~b}$ & $0.7 \mathrm{~B}$ & $0.9 \mathrm{~B}$ \\
\hline $\mathrm{CT}$ & $2.5 b$ & $74.2 \mathrm{~b}$ & $4.21 \mathrm{a}$ & $4.60 \mathrm{a}$ & $7.2 \mathrm{a}$ & $3.7 \mathrm{~A}$ & $6.2 \mathrm{~A}$ \\
\hline
\end{tabular}

BbX: Brachiaria brizantha cv. Xaraés; BbP: Brachiaria brizantha cv. Piatã; BbM: Brachiaria brizantha cv. Marandu; Bdec: Brachiaria decumbens; Br: Brachiaria ruziziensis; CT: conventional tillage. Size classes: A: 2-8 mm; B: 1-2 mm; C: 0.5-1 mm; D: 0.25-0.5 mm; E: 0.106-0.25 mm; F: $<0.106 \mathrm{~mm}$. For the same layer, values followed by different letters are significantly different according to the Scott-Knott test $(\mathrm{P} \leq 0.05)$.

The $B b$ cultivars and $B d e c$ stood out in relation to the fallow control in terms of the restoration of the soil structure, as evaluated by the LLWR in all layers. The magnitude of this indicator showed the following sequence: $\mathrm{LLWR}_{B b X}>\mathrm{LLWR}_{B b \mathrm{P}}>$ $\mathrm{LLWR}_{B b \mathrm{M}}>\mathrm{LLWR}_{B d e c}$ (Figure 1).

On the other hand, the species $B r$ showed limited potential in terms of soil recovery in comparison to the other species of Brachiaria, with LLWR conditions similar to those found in the fallow control (Figure 1).

Moreover, the highest amplitudes of the LLWR were observed in all layers of the soil under CT, indicating that the disturbances caused by soil preparation is effective in removing compacted layers (Figure 1). 
With respect to the values of GMD (Table treatments except for CT, there were discrepancies 3 ) in association with the LLWR (Figure 1), in the amplitude of the LLWR detected among the although no differences were detected in any of the conservationist systems.

Figure 1. Variation in soil water content $\left(\theta, \mathrm{dm}^{3} \mathrm{dm}^{-3}\right)$ according to depth for critical values of the least limiting water range in a Distroferric Red Latosol in the municipality of Rio Verde, state of Goiás. BbX: Brachiaria brizantha cv. Xaraés; BbP: Brachiaria brizantha cv. Piatã; BbM: Brachiaria brizantha cv. Marandu; Bdec: Brachiaria decumbens; Br: Brachiaria ruziziensis; CT: conventional tillage.

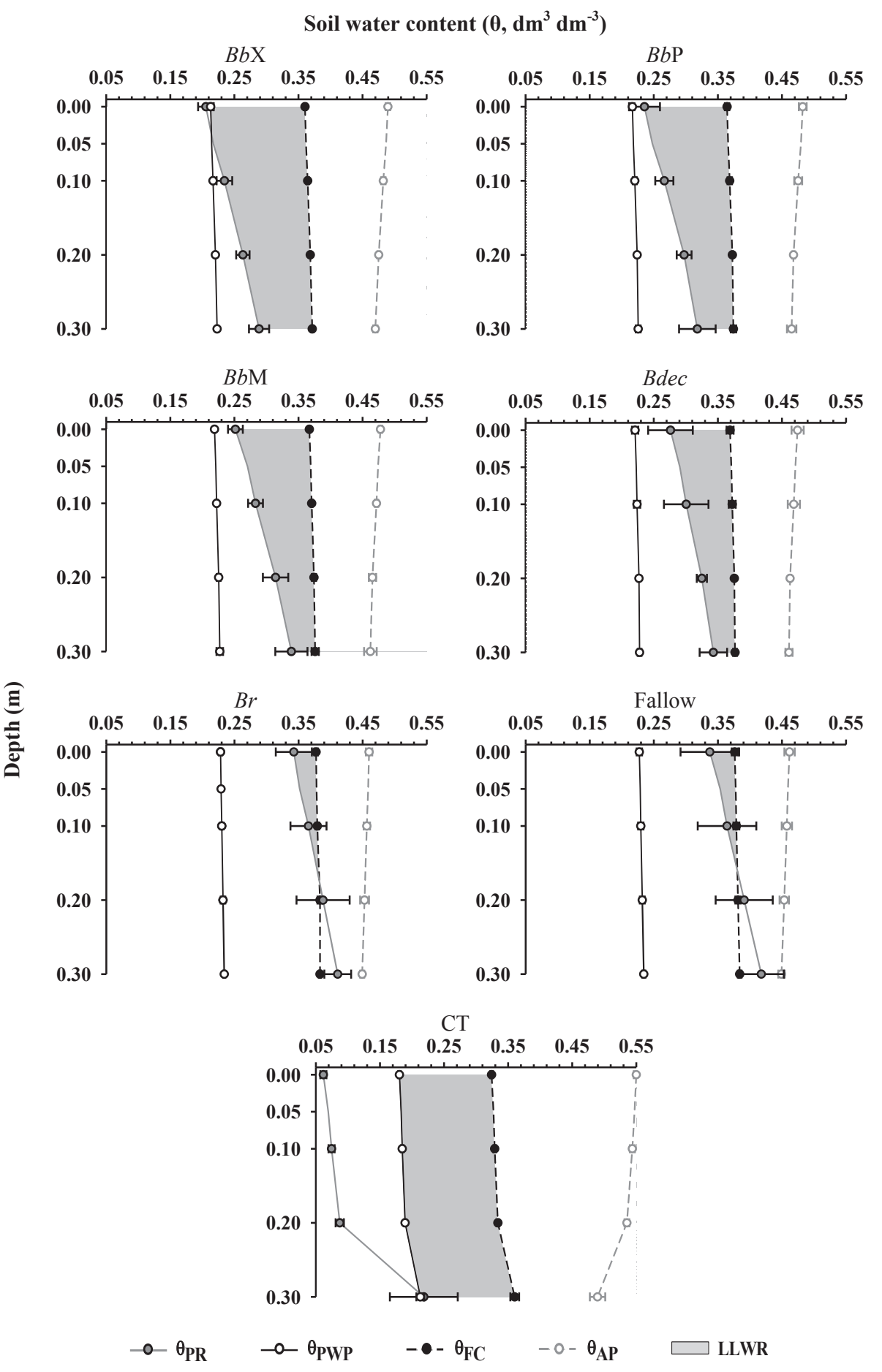


Figure 2. Pearson correlations between physical quality indicators and total organic carbon in a Distroferric Red Latosol in the municipality of Rio Verde, state of Goiás, under different soil management systems.
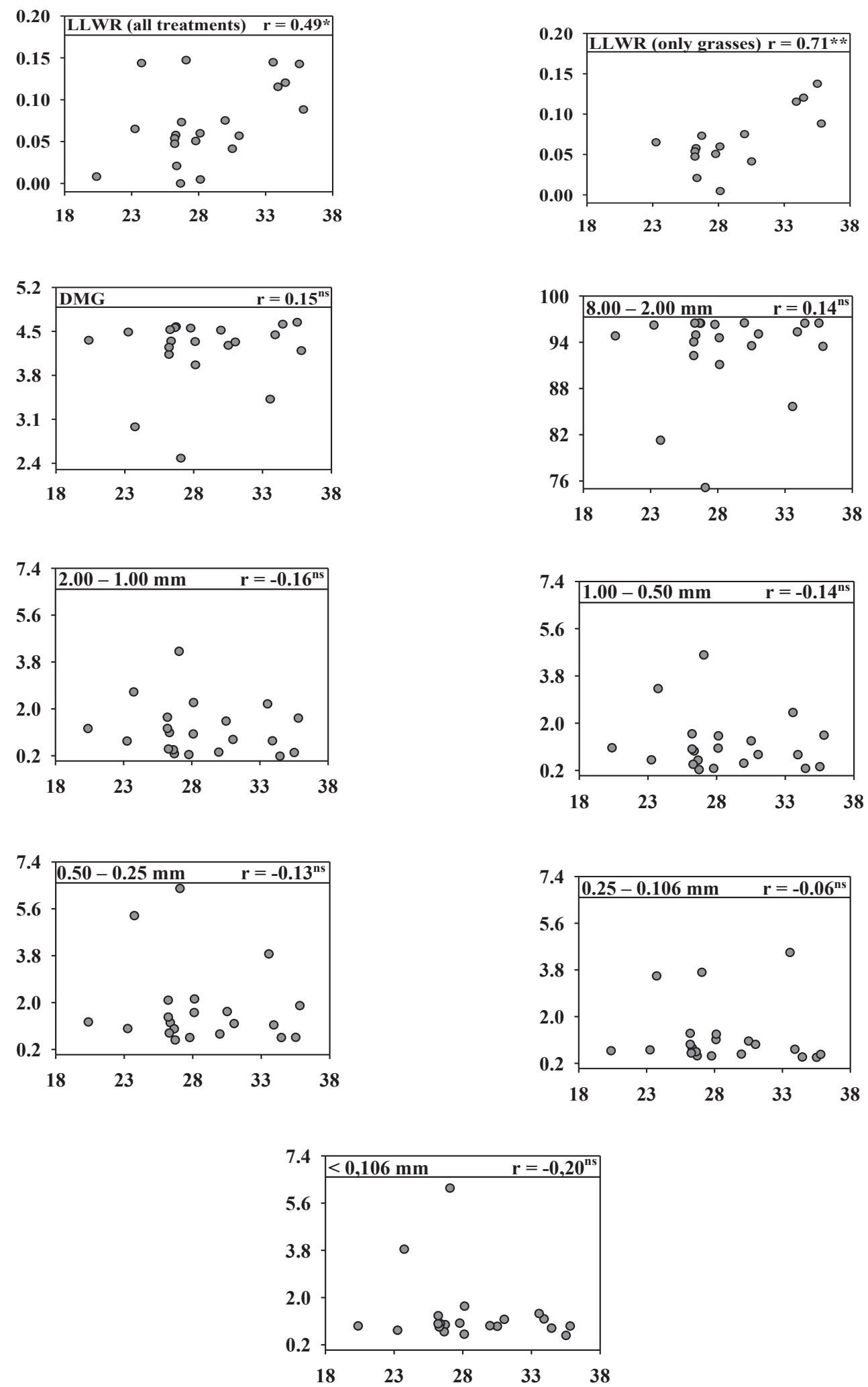

Total organic carbon in soil $\left(\mathrm{g} \mathrm{dm}^{-3}\right)$ 
We observed a weak but significant correlation $\left(\mathrm{r}=0.49^{*}\right)$ between the LLWR and TOC when considering all treatments evaluated in the study (Figure 2). A stronger correlation was found between the LLWR and TOC $\left(r=0.71^{* *}\right)$ when the analysis was restricted to the integrated systems including grasses.

\section{Discussion}

The small increases in the total organic carbon (TOC) levels promoted by $B$. brizanth $(B b)$ and $B$. decumbens $(B d e c)$ in the soil surface layer $(0-0.1 \mathrm{~m})$ were consistent with the biomass added to the soil by the root systems (TRUJILLO et al., 2006).

The lowest TOC content found under conventional tillage (CT) in relation to that in the other treatments occurred due to the soil revolving performed by the rotary tiller and the consequent disruption of aggregates in the surface layer of the soil. In this case, the elimination of the physical protection of organic matter and exposure to attack by aerobic microorganisms occur (TISDALL; OADES, 1982), which can lead to the rapid loss of soil carbon as $\mathrm{CO}_{2}$ and subsequently contribute to the greenhouse effect and global warming (OLIVEIRA et al., 2004).

The finding of the highest TOC content in the soil under CT in the 0.1-0.2 m layer can be explained by the inversion of layers caused by the preparation machinery because the observed values are similar to those found at the surface in all treatments without soil tillage and because sampling was performed immediately after ploughing.

The TOC values observed in the treatments including the cultivation of grasses and $\mathrm{CT}$ in the $0.2-0.3 \mathrm{~m}$ layer are likely due to the input and/ or maintenance of carbon promoted by the roots of grasses and by the incorporation of corn plant residues, respectively. In this way, the lower TOC content observed in the fallow soil suggests that the root system of the weeds failed to incorporate carbon into the deeper layers (deeper than 0.2 $\mathrm{m}$ ), most likely due to the pivoting root system of most species in this treatment, which belong to the subclass Dicotyledoneae.

Despite the differences in TOC values among the treatments, these values are numerically small. This is because of the slow and gradual increase of carbon in the soil, which even occurs as a result of the correct establishment and maintenance of conservation management systems over long periods of time (ASSIS; LANÇAS, 2005), especially in tropical soils, where organic matter mineralization tends to overcome the inputs (TIRLONI et al., 2012).

In contrast, structural changes can occur in a short time, both in terms of degradation, if the pressure applied by machinery and grazing animals overcome the soil load bearing capacity (ZINK et al., 2010; SEVERIANO et al., 2013), and the recovery via mechanical or biological loosening (SEVERIANO et al., 2010; FLÁVIO NETO et al., 2015). Such findings are essential for the interpretation of the results presented below given the importance of root growth and organic matter in soil aggregation (BRANDÃO; SILVA, 2012).

Soils that are disturbed have lower geometric mean diameter (GMD) values compared to those under conservation systems as a result of a decrease in the number macroaggregates $(>2 \mathrm{~mm})$, which are disrupted by the action of machinery on the soil. This fact justifies the absence of differences in GMD values observed across all the evaluated systems and layers except for CT (Table 3).

The GMD values remained high even in all layers in treatments without soil revolving when compared to the values obtained by Tirloni et al. (2012) in a very clayey Latosol. This is because the stability of aggregates can rapidly increase with the inclusion of pasture in the crop rotation process due to the lack of soil revolving, the constant renewal of the vigorous root system and the increased activity of soil fauna under pasture (MARCHÃO et al., 
2007). Similar results were reported by Silva and Mielniczuk (1998), who observed a positive role of grass cultivation on aggregate stability and organic carbon in a similar soil.

Moreover, Conte et al. (2011) observed higher levels of soil aggregation in grazed areas compared to those without grazing, indicating the formation of clods via soil compaction due to animal trampling. In this sense, the observation of the greatest values of GMD (4.6) in the soil under $B b \mathrm{P}$ and $B b X$, which were equal to that in the fallow soil, could be associated with soil compaction, thereby indicating the possible existence of historical degradation resulting from previous soil management. This result requires further investigation regarding the accuracy of the assessment of aggregation in the evaluation of soil structural quality.

A diameter of $0.25 \mathrm{~mm}$ is the threshold between macro- and microaggregates in the soil (OADES; WATERS, 1991). The high percentage of aggregates (95\%) retained in the sieves with a mesh size $\geq$ $0.25 \mathrm{~mm}$ in all treatments and soil layers (Table 3) when analysed alone indicates that almost all of the aggregates found in the experimental soil are at advanced stages of aggregation, suggesting high physical quality. Systems that promote the formation of stable macroaggregates are desirable because they support higher applications of external forces without disruption, conferring greater resistance to compaction and erosion to the soil (SEVERIANO et al., 2008; SALTON et al., 2008).

In agreement with Daynes et al. (2013), the soil aggregation process is associated with dynamic and dependent phenomena, including the effects of the biota on soil organic matter and the influence of the root system of the growing plants on the unit particles, among other factors. In this sense, the continuous input of plant residues observed in crop-livestock integration systems ensures a positive balance in terms of aggregation, while soil revolving, which was observed in $\mathrm{CT}$, for example, may be related to lower aggregate stability (OLIVEIRA et al., 2004).
Conversely, the results of our study indicate that the differences in the TOC content in the soil (Table 2) were small and therefore did not have a sufficient effect on soil aggregation to distinguish the treatments without soil revolving, with only differences between $\mathrm{CT}$ and other systems being identified (Table 3). This result therefore suggests that soil aggregation measures determined by wet sieving are not suitable for differentiating the effects of soil restructuring, in contrast to the formation of dense soil clods, which arise from root growth and the stabilization of macroaggregates or from compaction forces imposed on the soil.

The morphology of Oxidic Latosols is characterized by very small and resistant granular aggregates with diameters of 50-300 $\mu \mathrm{m}$ (FERREIRA et al., 1999; VOLLANT-TUDURI et al., 2005; CARDUCCI et al., 2011) with high structural stability and friability (VITORINO et al., 2003). In this context, it was observed that more than $90 \%$ of the soil aggregates were in the largest size class (2-8 $\mathrm{mm}$ ) in the treatments without soil revolving and in all evaluated layers (Table 3), being at least six times larger than the basic structural units of these soils, as described by the previously mentioned authors. Furthermore, it is emphasized that on the basis of the universally accepted methodology used in this study (KEMPER; ROSENAU, 1986), aggregates between 2.00 and $4.76 \mathrm{~mm}$ present in the soils are removed, which can limit the accuracy of the identification of soil physical quality.

This consideration reinforces the fact that our results are unclear regarding the origin of the soil aggregates, if they were formed by the cementing action of organic matter and the action of the root system of the studied grasses or from the accumulated compaction processes over the history of the degraded area. Thus, would have to be termed clods and not soil aggregates, as highlighted by Severiano et al. (2008).

Likewise, Silva et al. (2006b) observed that the GMD of soil aggregates increased with soil 
compaction due to the likely mechanical compaction that occurred as evidenced by the combination of soil particles, which led the authors to consider that the GMD is not a good indicator of the effects of soil physical degradation. This low efficiency of aggregate stability analysis by sieving in water was reported by Nichols and Toro (2011), and the numerical values also do not express the impacts of biological, mechanical or environmental factors on soil structure. Therefore, this method should be combined with other structural indicators for a more accurate evaluation of soil quality (MONCADA et al., 2013).

Thus, it is necessary to evaluate the physical quality of the soil subjected to crop-livestock integration with the cultivation of Brachiaria species using indicators with higher accuracy. The proposed use of the LLWR, as shown in Figure 1, involves combining different attributes into a single parameter, which represents a breakthrough for studies of soil biophysics, as noted by Tormena et al. (2007).

The water content at which the resistance to the critical penetration of $2.5 \mathrm{MPa}$ is reached $\left(\theta_{\mathrm{PR}}\right)$ affects most LLWR amplitudes because it is a dynamic property associated with soil compaction (VAZ et al., 2001; DEXTER et al., 2007). In contrast, the minimal aeration porosity of $10 \%$ did not limit the LLWR in any treatment or layer due to the porous character of Red Latosols, the predominantly oxidic mineralogy and granular structure of which confer the soil with high structural stability and friability, reflecting the agglutination of the solid fraction of the soil and interconnected pores (REATTO et al., 2009; SEVERIANO et al., 2013; FLÁVIO NETO et al., 2015).

The better performance of the $B b$ cultivars and $B d e c$ in terms of the amplification of the LLWR values in comparison to the fallow treatment suggests that the use of integrated management systems involving the cultivation of Brachiaria species, mainly $B b$, can be an alternative method that can be used to alleviate the harmful effects of compaction on soil structure. Such practices are of particular interest in the Cerrado region due to the high susceptibility of Oxidic Latosols in this region to compaction, as the occurrence of soil compaction is practically inevitable in this area as a result of machinery traffic and trampling by animals (SEVERIANO et al., 2013).

This behavior is understood when analysing the performance of $B b$ cultivars used in Brazilian agriculture. These grasses were developed by the breeding programme of Embrapa with an aim to obtain plants that are well adapted to the humid tropical climate conditions and chemically poor acidic soils found in the Brazilian Cerrado (VALLE et al., 2009). In turn, this region is characterized by two well-defined seasons (dry winter and rainy summer), which make livestock on pasture vulnerable to the effects of seasonality of forage production (COSTA et al., 2008; BUSTAMANTE et al., 2012).

These grass species are native to countries at low latitudes on the African continent (AMBIEL et al., 2008), where they were naturally exposed to stressful conditions of sunshine and seasonal water deficit. These effects were partially circumvented by the $\mathrm{C} 4$ photosynthetic apparatus, which guarantees the better use of incident radiation and more efficient water use (SAGE; ZHU, 2011; GUENNI et al., 2002). These characteristics were enhanced when breeding these cultivars, notably the Xaraés and Piatã palisadegrasses, and thus the higher metabolic activity during the dry off-season in the Brazilian Cerrado contributes to the growth of the root system, allowing the disruption of the compacted soil layers that are usually found in agricultural areas, as evidenced by Flávio Neto et al. (2015).

Therefore, our results indicate that in croplivestock integration systems, management of the forage genus in question can promote a significant improvement in soil physical properties, confirming 
the positive results obtained by Blanco-Canqui et al. (2011), who also worked with other species of cover crops in no-till systems, and Petean et al. (2010), who found that crop-livestock integration establishes a physical environment conducive to the development of plants because it prevents the overgrazing of pastures.

The structural improvement of the soil as a result of biological loosening promoted by the studied grasses during the livestock phase in integrated systems directly affects the development of crops in succession. In this sense, by assessing the recovery of a physically degraded soil by cultivating these grasses, Flávio Neto et al. (2015) reported that the cultivation of $B b \mathrm{X}$ and $B b \mathrm{P}$ alleviated the effects of seasonality and increased the water availability for soybean in succession, which mitigates water stress coincident with the phenological stages of higher water demand for this crop.

On the other hand, in the $\mathrm{Br}$ and fallow treatments (Figure 1), there was a gradual reduction in the LLWR until the intermediate layer (0.1-0.2 $\mathrm{m})$, when it became null. In such cases, any water content in the soil imposes limitations on plant growth due to the high resistance to penetration of the soil by the root system of the plants grown therein (SILVA et al., 2006a).

It is noteworthy, therefore, that the data obtained by the evaluation of the LLWR in crop-livestock integration systems under no-tillage conditions allow this indicator to be considered suitable for quantifying structural changes in soil grown with pastures, notably those containing $B b$ and $B d e c$, corroborating the results obtained by Leão et al. (2006).

Although having a nonlimited LLWR, and with smaller aggregate sizes in general, it is important to note that the CT treatment showed an increase in $\theta_{\mathrm{PR}}$ concomitant with a reduction in $\theta_{\mathrm{AFP}}$ starting at a depth of $0.2 \mathrm{~m}$, which possibly arose from the occurrence of a slightly compacted soil layer at the bottom of the furrow left by the implements used in soil preparation. Considering that this was due to historical use, these results highlight the importance of the prior physical correction of depth in the process of the conversion of agricultural land into no-tillage (OLIVEIRA et al., 2007) and crop-livestock integration systems, which is an established procedure in Brazil.

In contrast, although the greatest amplitude in the LLWR occurring under CT may indicate less soil compaction in this treatment, the distribution and connectivity of the porous system become impaired by the absence of the beneficial activity of grass roots on the soil structure (FRANZLUEBBERS; STUEDEMANN, 2008).

The discrepancy in terms of the LLWR amplitudes found in the conservationist systems (Figure 1) and the lack of differences in GMD behaviour in response to the types of soil cover (Table 3) demonstrate the ineffectiveness of the analysis of aggregate stability using wet sieving in distinguishing soil aggregates and clods formed by the compaction of soil particles. Compacted soils may show high stability of aggregates in water but inadequate distribution of the volume of macro- and micropores, resulting in reduced total soil porosity (SEVERIANO et al., 2008; CONTE et al., 2011).

Thus, the high GMD values observed in the $\mathrm{Br}$ and fallow treatments mainly occurred as a result of the history of soil physical degradation, an opposite process to the structuring maintained by the formation and stabilization of macroaggregates through the root system of grasses and input of organic carbon into the soil. Brandão and Silva (2012) evaluated the effect of $\mathrm{Br}$ on soil aggregation and observed that this grass has a low potential to increase GMD values, with no difference between treatments with and without grass for the percentage of aggregates larger than $1 \mathrm{~mm}$.

Nevertheless, the use of Brachiaria species in integrated systems for the recovery of degraded 
Latosol structure was generally efficient, except under $\mathrm{Br}$ cultivation. Furthermore, the biological soil loosening potential of $B b$ cultivars, mainly evidenced by the higher LLWR amplitude of the soil under these treatments, reinforces the results of Calonego et al. (2011) and Chioderoli et al. (2012) and helps confirm their potential to act positively in regard to soil aggregation. Such effects are associated with the abundance and aggressiveness of the root system of these grasses and their efficiency in terms of the exudation of organic compounds (SANTOS et al., 2012).

The differential action of grass roots during the livestock phase of the integration system in terms of soil physical improvement is emphasized. By growing through the soil profile, roots contribute to an increase in TOC (Table 2) and biological soil loosening (Figure 1), although there was no effect on the aggregation parameters evaluated via wet sieving (Table 3). This is verified by the Pearson correlation analysis illustrated in Figure 2, where there is a positive correlation between the LLWR and TOC but not between the aggregation attributes and TOC.

The weak correlation $\left(\mathrm{r}=0.49^{*}\right)$ between the LLWR and TOC, when considering all treatments evaluated in the study (Figure 2), is due to CT, which promotes the mechanical disruption of soil clods and the inversion of soil layers, increasing the amplitude of the LLWR but also changing the arrangement of carbon in the soil profile.

On the other hand, the stronger correlation between the LLWR and TOC $\left(r=0.71^{* *}\right)$ for only the integrated systems with grasses can be explained by the growth and subsequent decomposition of grass roots, resulting in the formation of biopores that contribute to the reduction of soil density and, consequently, the other related physical attributes as well as an increase in carbon in the soil layers used by the grass (TIRLONI et al., 2012).

\section{Conclusions}

The crop-livestock integration system recovered the structure of the Latosol, with the diagnosis of physical resilience being related to the adopted quality indicator as well as to the Brachiaria genotype used.

Aggregate stability is not a good indicator for quantifying the potential for soil structure recovery compared the evaluated treatments, as it did not elucidate the effects of the adopted management systems on soil structure and did not distinguish soil aggregation from compaction. In turn, the LLWR is a better indicator of the assessed management systems, indicating the potential for recovery of soil structure.

Our results show that the cultivation of $B b X$ and $B b \mathrm{P}$ is promising in terms of biological soil loosening to a layer of $0.3 \mathrm{~m}$, with greater impacts on the surface layers. In addition, the efficiency of Xaraés palisadegrass indicates its potential use as a management strategy in soil recovery in croplivestock integration systems.

\section{Acknowledgements}

The author thanks the IF Goiano (Federal Institute of Education, Science and Technology Goiano) for support of our research and the FAPEG (Fundação de Amparo à Pesquisa do Estado de Goiás) for partial funding of our research, Call 09/2010 ProPós (Process number 201010267000906).

\section{References}

AMBIEL, A. C.; GUABERTO, L. M.; VANDERLEI, T. M.; MACHADO NETO, N. B. Agrupamento de acessos e cultivares de três espécies de Brachiaria por RAPD. Acta Scientiarum. Agronomy, Maringá, v. 30, n. 4, p. 457-464, 2008. DOI: 10.4025/actasciagron.v30i4.5298

ASSIS, R. L.; LANÇAS, K. P. Avaliação da compressibilidade de um Nitossolo Vermelho distroférrico sob sistema plantio direto, preparo convencional e mata nativa. Revista Brasileira de Ciência do Solo, Viçosa, v. 29 , n. 4 , p. $507-514,2005$. DOI: $10.1590 / \mathrm{S} 0100-$ 
06832005000400003

BLANCO-CANQUI, H.; MIKHA, M. M.; PRESLEY, D. R.; CLAASSEN, M. M. Addition of cover crops enhances no-till potential for improving soil physical properties. Soil Science Society of America Journal, Madison, v. 75, n. 4, p. 1471-1482, 2011. DOI: 10.2136/sssaj2010.0430

BRANDÃO, E. D.; SILVA, I. F. Formação e estabilização de agregados pelo sistema radicular de braquiária em um Nitossolo Vermelho. Ciência Rural, Santa Maria, v. 42, n. 7, p. 1193-1199, 2012. DOI: 10.1590/S010384782012000700009

BUSSCHER, W. J. Adjustment of flat-tipped penetrometer resistance data to common water content. Transactions of the ASAE, St. Joseph, v. 33, n. 2, p. 519524, 1990. DOI: 10.13031/2013.31360

BUSTAMANTE, M. M. C.; NOBRE, C.A.; SMERALDI, R.; AGUIAR, A. P. D.; BARIONI, L. G.; FERREIRA, L. G.; LONGO, K.; MAY, P.; PINTO, A. S.; OMETTO, J. P. H. Estimating greenhouse gas emissions from cattle raising in Brazil. Climatic Change, Dordrecht, v. 115, n. 3-4, p. 559-577, 2012. DOI: 10.1007/s10584-012-0443-3

CARDUCCI, C. E.; OLIVEIRA, G. C.; SEVERIANO, E. C.; ZEVIANI, W. M. Modelagem da curva de retenção de água de Latossolos utilizando a Equação Duplo Van Genuchten. Revista Brasileira de Ciência do Solo, Viçosa, v. 35, n. 1, p. 77-86, 2011. DOI: 10.1590/S010006832011000100007

CHIODEROLI, C. A.; MELLO, L. M. M.; GRIGOLLI, P. J.; FURLANI, C. E. A.; SILVA, J. O. R.; CESARIN, A. L. Physical properties of soil and yield of soybeans in corn braquiaria consortium. Revista Brasileira de Engenharia Agrícola e Ambiental, Campina Grande, v. 16, n. 1, p. 37-43, 2012. DOI: 10.1590/S1415-43662012000100005

CAlONEGO, J. C.; BORGHI, E.; CRUSCIOL, C. A. C. Intervalo hídrico ótimo e compactação do solo com cultivo consorciado de milho e braquiária. Revista Brasileira de Ciência do Solo, Viçosa, v.35, n.6, p.21832190, 2011. DOI: 10.1590/S0100-06832011000600033

CONTE, O.; FLORES, J. P. C.; CASSOL, L. C.; ANGHINONI, I.; CARVALHO, P. C. F.; LEVIEN, R.; WESP, C. L. Evolução de atributos físicos de solo em sistema de integração lavoura-pecuária. Pesquisa Agropecuária Brasileira, Brasília, v. 46, n. 10, p. 13011309, 2011. DOI: 10.1590/S0100-204X2011001000026

COSTA, K. A. P.; FAQUIN, V.; OLIVEIRA, I. P.; RODRIGUES, C.; SEVERIANO, E. C. Doses e fontes de $\mathrm{N}$ em pastagem de capim-marandu. I - Alterações nas características químicas do solo. Revista Brasileira de Ciência do Solo, Viçosa, v. 32, n. 4, p. 1591-1599, 2008. DOI: $10.1590 / \mathrm{S} 0100-06832008000400023$
CRUVINEL, W. S.; COSTA, K. A. P.; SILVA, A. G.; SEVERIANO, E. C.; RIBEIRO, M. G. Intercropping of sunflower with Brachiaria brizantha cultivars during two sowing seasons in the interim harvest. Semina. Ciências Agrárias, Londrina, v. 38, n. 5, p. 3173-3192, 2017. DOI: $10.5433 / 1679-0359.2017 \mathrm{v} 38 \mathrm{n} 5 \mathrm{p} 3173$

DAYNES, C. N.; FIELD, D. J.; SALEEBA, J. A.; COLE, M. A.; MCGEE, P. A. Development and stabilisation of soil structure via interactions between organic matter, arbuscular mycorrhizal fungi and plant roots. Soil Biology and Biochemistry, Leicestershire, v. 57, n. 1, p. 683-694, 2013. DOI: 10.1016/j.soilbio.2012.09.020

DEXTER, A. R.; CZYZ, E. A.; GATE, O. P. A method for prediction of soil penetration resistance. Soil and Tillage Research, Amsterdam, v. 93, n. 2, p. 412-419, 2007. DOI: 10.1016/j.still.2006.05.011

FERREIRA, M. M.; FERNANDES, B.; CURI, N. Mineralogia da fração argila e estrutura de Latossolos da região sudeste do Brasil. Revista Brasileira de Ciência do Solo, Viçosa, v. 23, n. 3, p. 507-514, 1999. DOI: 10.1590/ S0100-06831999000300003

FERREIRA, L. G.; FERNANDEZ, L. E.; SANO, E. E.; FIELD, C.; SOUSA, S. B.; ARANTES, A. E.; ARAÚJO, F. M. Biophysical properties of cultivated pastures in the Brazilian savanna biome: an analysis in the spatialtemporal domains based on ground and satellite data. Remote Sensing, Basel, v. 5, n. 1, p. 307-326, 2013. DOI: $10.3390 /$ rs5010307

FLÁVIO NETO, J.; SEVERIANO, E. C.; COSTA, K. A. P.; GUIMARÃES JÚNNYOR, W. S.; GONCALVES, W. G.; ANDRADE, R. Biological soil loosening by grasses from genus Brachiaria in crop-livestock integration. Acta Scientiarum. Agronomy, Maringá, v. 37, n. 3, p. 375, 2015. DOI: 10.4025 /actasciagron.v37i3.19392

FRANZLUEBBERS, A. J.; STUEDEMANN, J. A. Soil physical responses to cattle grazing cover crops under conventional and no tillage in the Southern Piedmont USA. Soil and Tillage Research, Amsterdam, v. 100, n. 1-2, p. 141-153, 2008. DOI: 10.1016/j.still.2008.05.011

GARCÍA-PRÉCHAC, F.; ERNST, O; SIRI-PRIETO, G.; TERRA, J. A. Integrating no-till into crop-pasture rotations in Uruguay. Soil and Tillage Research, Amsterdam, v. 77, n. 1, p. 1-13, 2004. DOI: 10.1016/j. still.2003.12.002

GUENNI, O.; MARIN, D.; BARUCH, Z. Responses to drought of five Brachiaria species. I. Biomass production, leaf growth, root distribution, water use and forage quality. Plant and Soil, The Hague, v. 243, n. 2, p. 229-241, 2002. DOI: 10.1023/A:1019956719475 
HORN, R.; DOMZAL, H.; SLOWIŃSKAJURKIEWICZ, A.; OUWERKERK, C. V. Soil compaction processes and their effects on the structure of arable soils and the environment. Soil and Tillage Research, Amsterdam, v. 35, n. 1/2, p. 23-36, 1995. DOI: 10.1016/0167-1987(95)00479-C

KEMPER, W. D.; CHEPIL, W. S. Size distribution of aggregates. In: BLACK, C. A. (Ed.). Methods of soil analysis. Madison: American Society of Agronomy, 1965. p. 449-510.

KEMPER, W. D.; ROSENAU, R. C. Aggregate stability and size distribution. In: KLUTE, A. (Ed.). Methods of soil analysis. Madison: American Society of Agronomy, 1986. p. 425-442.

KONG, A. Y. Y.; SIX, J.; BRYANT, D. C.; DENISON, R. F.; VAN KESSEL, C. The relationship between carbon input, aggregation, and soil organic carbon stabilization in sustainable cropping systems. Soil Science Society of America Journal, Madison, v. 69, n. 4, p. 1078-1085, 2005. DOI: $10.2136 /$ sssaj2004.0215

LEÃO, T. P.; SILVA, A. P. A simplified Excel ${ }^{\circledR}$ algorithm for estimating the least limiting water range of soils. Scientia Agricola, Piracicaba, v.61, n.6, p.649-654, 2004. DOI: 10.1590/S0103-90162004000600013

LEÃO, T. P.; SILVA, A. P.; MACEDO, M. C. M.; IMHOFF, S.; EUCLIDES, V. P. B. Least limiting water range: a potential indicator of changes in near-surface soil physical quality after the conversion of Brazilian Savanna into pasture. Soil and Tillage Research, Amsterdam, v. 88 , n. 1-2, p. 279-285, 2006. DOI: 10.1016/j.still.2005.06.014

LIMA, V. M. P.; OLIVEIRA, G. C.; SERAFIM, M. E.; CURI, N.; EVANGELISTA, A. R. Intervalo hídrico ótimo como indicador de melhoria da qualidade estrutural de Latossolo degradado. Revista Brasileira de Ciência do Solo, Viçosa, v. 36, n. 1, p. 71-78, 2012. DOI: 10.1590/ S0100-06832012000100008

MAIA, G. A.; COSTA, K. A. P.; SEVERIANO, E. C.; EPIFÂNIO, P. S.; FLÁVIO NETO, J.; RIBEIRO, M. G.; FERNANDES, P. B.; SILVA, J. F. G.; GONÇALVES, W. G. Yield and chemical composition of Brachiaria forage grasses in the offseason after corn harvest. American Journal of Plant Science, Mississipi State, v. 5, n. 7, p. 933-941, 2014. DOI: 10.4236/ajps.2014.57106

MARCHÃO, R. L.; BALBINO, L. C.; SILVA, E. M.; SANTOS JUNIOR, J. D. G.; SÁ, M. A. C.; VILELA, L.; BECQUER, T. Qualidade física de um Latossolo Vermelho sob sistemas de integração lavoura-pecuária no Cerrado. Pesquisa Agropecuária Brasileira, Brasília, v. 42 , n. 6 , p. $873-882,2007$. DOI: $10.1590 / \mathrm{S} 0100-$ 204X2007000600015
MONCADA, M. P.; GABRIELS, D.; CORNELIS, W.; LOBO, D. Comparing aggregate stability tests for soil physical quality indicators. Land Degradation and Development, Swansea, v. 26, n. 8, p. 843-852, 2013. DOI: $10.1002 / \mathrm{ldr} .2225$

NAWAZ, M. F.; BOURRIÉ, G.; TROLARD, F. Soil compaction impact and modelling. A review. Agronomy for Sustainable Development, Paris, v. 33, n. 2, p. 291309, 2013. DOI: 10.1007/s13593-011-0071-8

NICHOLS, K. A.; TORO, M. A whole soil stability index (WSSI) for evaluating soil aggregation. Soil and Tillage Research, Amsterdam, v. 111, n. 2, p. 99-104, 2011. DOI: 10.1016/j.still.2010.08.014

NUNES, U. R.; ANDRADE JÚNIOR, V. C.; SILVA, E. B.; SANTOS, N. F.; COSTA, H. A. O.; FERREIRA, C. A. Produção de palhada de plantas de cobertura e rendimento do feijão em plantio direto. Pesquisa Agropecuária Brasileira, Brasília, v. 41, n. 6, p. 943-948, 2006. DOI: $10.1590 / \mathrm{S} 0100-204 X 2006000600007$

OADES, J. M. Soil organic matter and structural stability: mechanisms and implications for management. Plant and Soil, The Hague, v. 76, n. 1-3, p. 319-337, 1984. DOI: $10.1007 / \mathrm{BF} 02205590$

OADES, J. M.; WATERS, A. G. Aggregate hierarchy in soils. Australian Journal of Soil Research, Melbourne, v. 29 , n. 6 , p. $815-828$, 1991. DOI: 10.1071/SR9910815

OLIBONE, D.; OLIBONE, A. P. E.; ROSOLEM, C. A. Least limiting water range and crop yields as affected by crop rotations and tillage. Soil Use and Management, Wallingford, v. 26, n. 4, p. 485-493, 2010. DOI: 10.1111/j.1475-2743.2010.00301.x

OLIVEIRA, G. C.; DIAS JUNIOR, M. S.; RESCK, D. V. S.; CURI, N. Caracterização química e físico-hídrica de um Latossolo Vermelho após vinte anos de manejo e cultivo do solo. Revista Brasileira de Ciência do Solo, Viçosa, v. 28, n. 2, p. 327-336, 2004. DOI: 10.1590/ S0100-06832004000200011

OLIVEIRA, G. C.; SEVERIANO, E. C.; MELLO, C. R. Dinâmica da resistência à penetração de um Latossolo Vermelho da Microrregião de Goiânia, GO. Revista Brasileira de Engenharia Agrícola e Ambiental, Campina Grande, v. 11, n. 3, p. 265-270, 2007. DOI: $10.1590 /$ S1415-43662007000300004

PACHECO, L. P.; LEANDRO, W. M.; MACHADO, P. L. O. A.; ASSIS, R. L.; COBUCCI, T.; MADARI, B. E.; PETTER, F. A. Produção de fitomassa e acúmulo e liberação de nutrientes por plantas de cobertura na safrinha. Pesquisa Agropecuária Brasileira, Brasília, v. 46, n. 1, p. $17-25$, 2011. DOI: 10.1590/S0100204X2011000100003 
PÉRÈS, G.; CLUZEAU, D.; MENASSERI, S.; SOUSSANA, J. F.; BESSLER, H.; ENGELS, C.; HABEKOST, M.; GLEIXNER, G.; WEIGELT, A.; WEISSLER, W. W.; SCHEU, S.; EISENHAUER, N. Mechanisms linking plant community properties to soil aggregate stability in an experimental grassland plant diversity gradient. Plant and Soil, The Hague, v. 373, n. 1-2, p. 285-299, 2013. DOI: 10.1007/s11104-013-1791-0

PETEAN, L. P.; TORMENA, C. A.; ALVES, S. J. Intervalo hídrico ótimo de um Latossolo Vermelho distroférrico sob plantio direto em sistema de integração lavoura-pecuária. Revista Brasileira de Ciência do Solo, Viçosa, v. 34, n. 5, p. 1515-1526, 2010. DOI: 10.1590/ S0100-06832010000500004

RAWLINS, B. G.; WRAGG, J.; LARK, R. M. Application of a novel method for soil aggregate stability measurement by laser granulometry with sonication. European Journal of Soil Science, Cranfield, v. 64, n. 1, p. 92-103, 2013. DOI: 10.1111/ejss. 12017

REATTO, A.; BRUAND, A.; MARTINS, E. S.; MULLER, F.; SILVA, E. M.; CARVALHO JÚNIOR, O. A.; BROSSARD, M.; RICHARD, G. Development and origin of the microgranular structure in Latosols of the Brazilian Central Plateau: significance of texture, mineralogy, and biological activity. Catena, Amsterdam, v. 76, n. 2, p. 122-134, 2009. DOI: 10.1016/j. catena.2008.10.003

SAGE, R. F.; ZHU, X. G. Exploiting the engine of C4 photosynthesis. Journal of Experimental Botany, Oxford, v. 62 , n. 9 , p. $2989-3000,2011$. DOI: $10.1093 /$ jxb/err179

SALTON, J. C.; MIELNICZUK, J.; BAYER, C.; BOENI, M.; CONCEIÇÃO, P. C.; FABRÍCIO, A. C.; MACEDO, M. C. M.; BROCH, D. L. Agregação e estabilidade de agregados do solo em sistemas agropecuários em Mato Grosso do Sul. Revista Brasileira de Ciência do Solo, Viçosa, v. 32, n. 1, p. 11-21, 2008. DOI: 10.1590/S010006832008000100002

SANO, E. E.; ROSA, R.; BRITO, J. L. S.; FERREIRA, L. G. Land cover mapping of the tropical savanna region in Brazil. Environmental Monitoring Assessment, New York, v. 166, n. 1-4, p. 113-124, 2010. DOI: 10.1007/ s10661-009-0988-4

SANTOS, G. G.; SILVEIRA, P. M.; MARCHÃO, R. L.; PETTER, F. A.; BECQUER, T. Atributos químicos e estabilidade de agregados sob diferentes culturas de cobertura em Latossolo do cerrado. Revista Brasileira de Engenharia Agrícola e Ambiental, Campina Grande, v. 16 , n. 11, p. 1171-1178, 2012. DOI: 10.1590/S141543662012001100005

SANTOS, H. G.; JACOMINE, P. K. T.; ANJOS, L. H. C.; OLIVEIRA, V. A.; LUMBRERAS, J. F.; COELHO,
M. R.; ALMEIDA, J. A.; ARAUJO FILHO, K. C.; OLIVEIRA, J. B.; CUNHA, T. J. F. Sistema brasileiro de classificação de solos. 5. ed. Brasília: EMBRAPA Solos, 2018. 356 p.

SEVERIANO, E. C.; OLIVEIRA, G. C.; DIAS JUNIOR, M. S.; COSTA, K. A. P.; CASTRO, M. B.; MAGALHÃES, E. N. Potencial de descompactação de um Argissolo promovido pelo capim-tifton 85. Revista Brasileira de Engenharia Agrícola e Ambiental, Campina Grande, v. 14, n. 1, p. 39-45, 2010. DOI: 10.1590/S141543662010000100006

SEVERIANO, E. C.; OLIVEIRA, G. C.; DIAS JÚNIOR, M. S.; COSTA, K. A. P.; SILVA, F. G.; FERREIRA FILHO, S. M. Structural changes in Latosols of the cerrado region: I - relationships between soil physical properties and least limiting water range. Revista Brasileira de Ciência do Solo, Viçosa, v. 35, n. 3, p. 773782, 2011. DOI: 10.1590/S0100-06832011000300013

SEVERIANO, E. C.; OLIVEIRA, G. C.; DIAS JUNIOR, M. S.; CURI, N.; COSTA, K. A. P.; CARDUCCI, C. E. Preconsolidation pressure, soil water retention characteristics, and texture of Latosols in the Brazilian Cerrado. Soil Research, Melbourne, v. 51, n. 3, p. 193202, 2013. DOI: 10.1071/SR12366

SEVERIANO, E. C.; OLIVEIRA, G. C.; DIAS JÚNIOR, M. S.; OLIVEIRA, L. F. C.; CASTRO, M. B. Pressão de preconsolidação e intervalo hídrico ótimo como indicadores de alterações estruturais de um Latossolo e de um cambissolo sob cana-de-açúcar. Revista Brasileira de Ciência do Solo, Viçosa, v. 32, n. 4, p. 1419-1427, 2008. DOI: $10.1590 /$ S0100-06832008000400006

SILVA, A. P.; KAY, B. D.; PERFECT, E. Characterization of the least limiting water range of soils. Soil Science Society of America Journal, Madison, v. 58, n. 6, p. 1775-1781, 1994. DOI: 10.2136/ sssaj1994.03615995005800060028x

SILVA, A. P.; KAY, B. D.; TORMENA, C. A.; IMHOFF, S. Least limiting water range of soils. In: LAL, R. (Ed.). Encyclopedia of soil science. New York: Taylor \& Francis Group, 2006a. p. 1026-1029.

SILVA, S. R.; BARROS, N. F.; COSTA, L. M. Atributos físicos de dois Latossolos afetados pela compactação do solo. Revista Brasileira de Engenharia Agrícola e Ambiental, Campina Grande, v.10, n.4, p.842-847, 2006b. DOI: $10.1590 /$ S1415-43662006000400009

SILVA, I. F.; MIELNICZUK, J. Sistemas de cultivo e características do solo afetando a estabilidade de agregados. Revista Brasileira de Ciência do Solo, Viçosa, v. 22, n. 2, p. 311-317, 1998. DOI: 10.1590/ S0100-06831998000200017 
SILVA, J. F. G.; SEVERIANO, E. C.; COSTA, K. A. P.; BENITES, V. M.; GUIMARÃES JÚNNYOR, W. S.; BENTO, J. C. Chemical and physical-hydric characterisation of a red latosol after five years of management during the summer between-crop season. Revista Brasileira de Ciência do Solo, Viçosa, v. 38 , n. 5, p. 1576-1586, 2014. DOI: 10.1590/S010006832014000500023

SILVA, S. R.; BARROS, N. F.; COSTA, L. M. Atributos físicos de dois Latossolos afetados pela compactação do solo. Revista Brasileira de Engenharia Agrícola e Ambiental, Campina Grande, v. 10, n. 4, p. 842-847, 2006b. DOI: 10.1590/S1415-43662006000400009

SOIL SCIENCE GLOSSARY TERMS COMMITTEE. Glossary of soil science terms 2008. Madison: SSSA, 2008. $92 \mathrm{p}$.

SOUZA, E. D.; COSTA, S. E. V. G. A.; ANGHINONI, I.; CARVALHO, P. C. F.; OLIVEIRA, E. V. F.; MARTINS, A. P.; CAO, E.; ANDRIGHETTI, M. Soil aggregation in a crop-livestock integration system under no-tillage. Revista Brasileira de Ciência do Solo, Viçosa, v. 34, n. 4, p. 1365-1374, 2010. DOI: 10.1590/S010006832010000400033

TEIXEIRA, P. C.; DONAGEMMA, G. K.; FONTANA, A.; TEIXEIRA, W. G. Manual de métodos de análise do solo. 3. ed. Brasília: EMBRAPA, 2017. 573 p.

TIRLONI, C.; VITORINO, A. C. T.; BERGAMIN, A. C.; SOUZA, L. C. F. Physical properties and particlesize fractions of soil organic matter in crop-livestock integration. Revista Brasileira de Ciência do Solo, Viçosa, v. 36, n. 4, p. 1299-1310, 2012. DOI: 10.1590/ S0100-06832012000400024.

TISDALL, J. M.; OADES, J. M. Organic matter and water-stable aggregates in soils. Journal of Soil Science, Oxford, v.33, n.2, p.141-163, 1982. DOI: 10.1111/j.13652389.1982.tb01755.x

TOLLEFSON, J. Food: the global farm. Nature, New York, v. 466, n. 1, p. 554-556, 2010. DOI: https://doi. org $/ 10.1038 / 466554 \mathrm{a}$

TORMENA, C. A.; ARAÚJO, M. A.; FIDALSKI, J.; COSTA, J. M. Variação temporal do intervalo hídrico ótimo de um Latossolo Vermelho distroférrico sob sistemas de plantio direto. Revista Brasileira de Ciência do Solo, Viçosa, v. 31, n. 2, p. 211-219, 2007. DOI: $10.1590 / \mathrm{S} 0100-06832007000200003$
TRUJILLO, W.; FISHER, M. J.; LAL, R. Root dynamics of native savanna and introduced pastures in the Eastern Plains of Colombia. Soil and Tillage Research, Amsterdam, v. 87, n. 1, p. 28-38, 2006. DOI: 10.1016/j. still.2005.02.038

VALLE, C. B.; JANK, L.; RESENDE, R. M. S. O melhoramento de forrageiras tropicais no Brasil. Revista Ceres, Viçosa, v. 56, n. 4, p. 460-472, 2009.

VAZ, C. M. P.; HOPMANS, J. W. Simultaneous measurement of soil penetration resistance and water content with a combined penetrometer-TDR moisture probe. Soil Science Society of America Journal, Madison, v. 65 , n. 1, p. $4-12$, 2001. DOI: 10.2136/sssaj2001.6514

VEZZANI, F. M.; MIELNICZUK, J. Uma visão sobre qualidade do solo. Revista Brasileira de Ciência do Solo, Viçosa, v. 33, n. 4, p. 743-755, 2009. DOI: 10.1590/ S0100-06832009000400001

VITORINO, A. C. T.; FERREIRA, M. M.; CURI N.; LIMA, J. M.; SILVA, M. L. N.; MOTTA, P. E. F. Mineralogia, química e estabilidade de agregados do tamanho de silte de solos da região sudeste do Brasil. Pesquisa Agropecuária Brasileira, Brasília, v. 38, n. 1, p. 133-141, jan. 2003. DOI: 10.1590/S0100204X2003000100018

VOLLANT-TUDURI, N.; BRUAND, A.; BROSSARD, M.; BALBINO, L. C.; OLIVEIRA, M. I. L.; MARTINS, E. S. Mass proportion of microaggregates and bulk density in a Brazilian clayey oxisol. Soil Science Society of American Journal, Madison, v. 69, n. 5, p. 1559-1564, 2005. DOI: 10.2136/sssaj2003.0344

YODER, R. E. A direct method of aggregate analysis of soil and a study of the physical nature erosion losses. Agronomy Journal, Madison, v. 28, n. 1, p. 337-351, 1936. DOI: 10.2134/agronj1936.000219620028000500 $01 \mathrm{x}$

ZINK, A., FLEIGE, H., HORN, R. Load risks of subsoil compaction and depths of stress propagation in arable Luvisols. Soil Science Society of America Journal, Madison, v. 74, n. 5, p. 1733-1742, 2010. DOI: 10.2136/ sssaj2009.0336

ZOTARELLI, L.; ALVES, B. J. R.; URQUIAGA, S.; TORRES, E.; SANTOS, H. P. dos; PAUSTIAN, K.; BODDEY, R. M. Impact of tillage and crop rotation on aggregate-associated carbon in two Oxisols. Soil Science Society of America Journal, Madison, v. 69, n. 2, p. 482491, 2005. DOI: 10.2136/sssaj2005.0482 